\title{
A tribute to Anselm Stanley Dissanaike
}

AS Dissanaike (Stanley to his friends) was born in Colombo on 29 October 1925. He had an uninterrupted education from the kindergarten to Form 5 at Richmond College, Galle. He describes the time spent at Richmond as glorious years, having participated in sports, drama, the school choir, extra-curricular activities such as scouting, and winning many prizes and scholarships on offer at that time.

He obtained the highest honours at all public examinations with First Division at the Junior and Senior School Certificate, London, Matriculation and the Higher School Certificate. The latter was achieved when he shifted to St. Peter's College, Colombo, in pursuit of university education. At St. Peter's, he was introduced to the world of parasites by the late Professor Hilary Crusz, then an Assistant Lecturer in Zoology at the University of Ceylon, who being an alumni of the college took classes for the college students free of charge. Under his influence Stanley developed a fascination for parasitology and obtained an exhibition to follow a course in zoology. He followed a BSc Special Zoology degree with parasitology as the special subject, and obtained first class honours. He has the honour of being the very first student in Sri Lanka to gain this distinction.

As Stanley's father was always keen on his becoming a doctor, Stanley resumed his career in medicine after clearing the First MB examination while still doing his zoology course. Thereafter, he passed the 2nd and 3rd MB with first class honours with several distinctions and won many scholarships and medals. He completed his medical degree obtaining second class honours at the Final MBBS with a distinction in Medicine. His colleague in the medical school, Dr. Victor Benjamin, describes him as the most academically outstanding student of their batch, earning the respect of all teachers.

Following a short stint as a House Officer in the State Health Services in Colombo and in his hometown Galle, he joined the academic circle as a Lecturer in Pathology at the Faculty of Medicine in 1952 and later, on return from London with the PhD in 1954, as a lecturer in the newly created Department of Parasitology in 1955.

In 1964 he was appointed to the Chair in Parasitology. He has the distinction of being the youngest, just 39 years old, to hold a professorship in the university system in Sri Lanka. He served as Dean at the Faculty of Medicine, Colombo from 1967 to 1970 , but resigned from the University to accept the Chair in Parasitology at the University of Malaya, in Kuala Lumpur. On resigning from this post in 1978, Stanley joined WHO in Geneva where he served in the Special Programme in research and training in tropical diseases. He was a member of the WHO Expert Committee in General Parasitology from 1964 until a few years ago. He is a highly competent and respected scientist in the field of filariasis and other parasitic diseases and regarded as a scientist of exceptional merit by his colleagues in Geneva.

To this day he is very active, alert, keenly interested in research and visits the Department of Parasitology, Faculty of Medicine, Colombo regularly. His scientific curiosity and encyclopaedic knowledge of the subject is unparalleled. He is a source of inspiration to all Sri Lankan scientists. He is a mentor to all of us in the field of Parasitology, always approachable and willing to offer advice and assistance. He has over 150 publications to his credit and though retired, continues to contribute to the literature on parasitology. His research has identified several parasites of zoonotic importance to humans and elucidated many of the life-cycles of parasites both in Sri Lanka and in Malaysia where he spent his later academic life. Zoonoses is his special interest, and he emphasised the importance of parasitic organisms crossing species barriers when opportune, a biological feature relating to major human infectious disease issues at present. Stanley has the distinction of having two parasites named after him. One a trematode (a fluke) Bilorchis dissanaikei, and the other a malarial parasite of parakeets, Plasmodium dissanaikei, discovered by his former student in London.

He has been principally responsible for broadening the knowledge of the Sri Lankan fauna of medically important parasites. Globally he is a recognised authority whose knowledge and expertise is still sought in many expert committees and scientific meetings. The University of London in 1966 awarded him the DSc in recognition of his outstanding contributions to parasitology. He remains to this day one of the few Sri Lankan scientists honoured to receive this prestigious degree. In 1977 he was awarded the Fellowship of the Royal College of Pathologists (UK). In 1995 he was conferred the title of Professor Emeritus of the University of Colombo.

As an individual he is soft spoken, calm, unassuming, and most importantly, a person of great integrity. Nevertheless he is a very sociable person, judged by his excellent organisation of the 50th Anniversary celebrations of his batch of 1952 held in Colombo in July 2002, which I was privileged to attend on invitation, as my late husband Dr. Chandra de S Wijesundera was also a student of this batch. The numerous anecdotes by Professor Dissanaike in the souvenir relating to eminent teachers and some of his more noted batchmates is witty and interesting, and reflects the lighter side of his personality.

I am privileged to give here some information obtained at a brief interview recently, which gives insight into his remarkable personality and also very importantly his views relating to the subject of parasitology, his chosen field of study. 
What made you choose an academic life when you had excelled in the clinical subjects, having obtained a distinction in Medicine?

During my work as a House Officer I was disillusioned with the unscientific method of many Consultants in applying knowledge to solve clinical problems. This prompted me to decide on an academic career.

You are known to excel in copper tooling and flower pressing.

I learned to do copper tooling in Malaysia and made it a hobby. My work included several parasites in addition to more classical work.

Flower pressing is still my favourite hobby and I do flower pressed greeting cards in my spare time.

Research is a heavy demand on time; how did your family view your long years of commitment to research?

My family, specially my wife Ellerine, gave me all the help and support during my research.

Could you identify the major contributions made by the WHO Special Programme for filariasis?

The major advances are:

a. Identification of the value of ivermectin in the control of onchocerciasis, and more recently, for lymphatic filariasis.

b. Use of albendazole and diethylcarbamazine alone or in combination for mass control programmes.

c. Recognising the value of cleansing elephantiasis skins.

d. Use of impregnated bednets for control of lymphatic filariasis.
How do you view the subject of medical parasitology as taught at present in the undergraduate medical curriculum in Sri Lanka?

I think medical parasitology is taught quite well, although different Faculties have their own methods of doing so.

What are your views on medical parasitology as a postgraduate programme separate from that of medical microbiology at the PGIM?

I feel quite strongly that medical parasitology should be a different entity.

Is there a need for other postgraduate courses in parasitology and related fields, e.g. medical entomology?

I feel they are adequate at present.

Could you give the major contributions of your research to the knowledge of parasitology in Sri Lanka?

I have been mostly interested and involved in parasitic zoonoses, and several of these infections have now been demonstrated and proved as predicted by me.

In your view, what are the challenges in medical parasitology in Sri Lanka, current and in the foreseeable future?

That's a difficult question. Many medical graduates prefer a career in clinical medicine and only a small number are devoted to laboratory research. Hence here is a need to attract better quality graduates, not only to work on the biochemistry and molecular biology of parasites but also to study basic parasite biology.

Manel K de Wijesundera, Professor in Parasitology, Faculty of Medicine, University of Peradeniya.

Correspondence: M K de W, e-mail:<wijem@sltnet.lk>. 